\title{
PENGARUH KEBIJAKAN $A T$ COST TERHADAP ALOKASI ANGGARAN PERJALANAN DINAS
}

\section{AA Nova Swandana}

Email: amertajati@gmail.com

\section{INTISARI}

Kebijakan penerapan mekanisme at cost pada perjalanan dinas membawa dampak pro dan kontra. Sampai dengan saat ini belum ada penelitian yang berusaha membahas mengenai pengaruh penerapan at cost tersebut. Penelitian ini merupakan tipe penelitian korelasional yang berusaha untuk menemukan pengaruh atas kebijakan tersebut pada alokasi anggaran perjalanan dinas dengan mengangkat variabel pagu anggaran, belanja barang, uang harian, dan transportasi. Jangkauan penelitan ini mulai dari tahun 2005 hingga 2011. Untuk menjawab rumusan masalah yang diajukan, digunakan metodologi analisis uji beda dan regresi statistika. Analisis uji beda untuk menguji apakah terdapat perbedaan antara sebelum dan sesudah penerapan at cost, dan regresi statistika untuk mengetahui secara lebih mendetail hubungan antara variabel dengan mekanisme at cost. Hasil yang didapat dari penelitian ini adalah bahwa terdapat perbedaan alokasi pagu perjalanan dinas antara sebelum dan sesudah penerapan at cost. Sedangkan variabel-variabel yang berpengaruh terhadap perjalanan dinas adalah: uang harian, pagu perjalanan dinas, dan pagu belanja barang. variabel-variabel tersebut mempengaruhi perjalanan dinas sebanyak $56 \%$. Selain itu, terdapat variabel lainnya yang memberikan kontribusi pengaruh sebesar $44 \%$ terhadap perjalanan dinas.

Kata kunci: perjalanan dinas, at cost, lump sum, belanja negara, anggaran sektor publik

\section{PENDAHULUAN}

\subsection{Latar belakang}

Bicara mengenai perjalanan dinas merupakan suatu hal yang menarik. Tidak hanya di negara berkembang seperti Indonesia, negara-negara maju pun memiliki permasalahan dalam mengefisienkan pengeluaran perjalanan dinas. Di Indonesia, semangat mengefisienkan belanja negara tercermin dari dikeluarkannya PMK 45/PMK.05/2007 tentang Perjalanan Dinas Jabatan Dalam Negeri Bagi Pejabat Negara,Pegawai Negeri, dan Pegawai Tidak Tetap (selanjutnya dalam tulisan ini disebut perjalanan dinas saja) pada tanggal 25 April
2007. Salah satu latar belakang keluarnya PMK tersebut adalah pertimbangan bahwa pembiayaan untuk perjalanan dinas harus sesuai dengan kebutuhan nyata dan memenuhi kaidah-kaidah pengelolaan keuangan negara. Karena itu perlu dilakukan perubahan pada cara pembayaran biaya perjalanan dinas, dari sebelumnya diberikan secara gelondongan (lumpsum) menjadi dihitung sesuai dengan kebutuhan riil (at cost) khususnya pada biaya transportasi dan penginapan.

Perubahan tersebut diharapkan menunjang pelaksanaan anggaran yang transparan dan akuntabel, dalam hal ini untuk menghindari peluang terjadinya praktek yang tidak sehat seperti 
menambah jumlah hari perjalanan. Sistem at cost dipercaya mampu memberikan manfaat efisiensi, karena:

1. Semua kebutuhan dalam pelaksanan perjadin difasilitasi

2. Pengeluaran benar-benar sesuai kenyataannya untuk mendukung pencapaian output

3. Meminimalisir tujuan untuk menambah penghasilan sehingga perjadin dilakukan benar-benar dalam kerangka mencapai output

4. Memudahkan pelaksanaan pemeriksaan karena terdapat bukti riil Secara psikologis, penerapan metode at cost yang sesuai dengan kebutuhan nyata dianggap akan mampu meningkatkan efisiensi perjalanan dinas sekaligus menurunkan tendensi melakukan perjalanan dinas untuk menambah penghasilan. Kenyataan bahwa pemerintahan daerah, pimpinan dan anggota DPRD juga mulai mengadopsi sistem at cost ini dengan terbitnya Permendagri Nomor 16/2013 tentang Pedoman Penyusunan APBD Tahun 2013 telah menunjukkan bahwa at cost betulbetul dipandang mampu meningkatkan efisiensi perjalanan dinas.

Disisi lain, terdapat suara penolakan terhadap penerapan at cost. Arus penolakan terhadap kebijakan ini mulai dari permintaan untuk kembali pada metode lumpsum karena at cost ditengarai mengurangi penghasilan sampai dengan anggapan bahwa at cost justru membawa konsekuensi lebih borosnya perjalanan dinas yang dilakukan.

Kini telah genap 8 tahun semenjak PMK 45/PMK.05/2007 diterbitkan, ternyata belum ada satupun penelitian yang berusaha menjawab apakah benar penerapan at cost tersebut berpengaruh terhadap alokasi anggaran.

\subsection{Tujuan Penelitian}

Tujuan penelitian ini adalah memberikan gambaran tentang ada tidaknya pengaruh pada alokasi anggaran sebagai dampak dari penerapan mekanisme at cost pada perjalanan dinas.

\subsection{Pertanyaan Penelitian}

Pertanyaan penelitian ini adalah:

1. Adakah perbedaan pada alokasi perjalanan dinas antara sebelum dan sesudah penerapan at cost?

2. Variabel apakah yang paling mempengaruhi perjalanan dinas?

\subsection{Pembatasan dan Perumusan Masalah}

Penelitian ini berupaya memberi jawaban ada tidaknya pengaruh penerapan metode at cost pada alokasi perjalanan dinas. Seluruh data perjalanan dinas pada APBN terekam dalam data server DJA, dan untuk mengaksesnya diperlukan interface. Interface yang dibangun oleh DJA sekarang hanya memfasilitasi akses mulai dari tahun anggaran 2005, sehingga data yang ideal tidak dapat diperoleh, diantaranya adalah volume perjalanan dinas. Selain itu, beberapa perubahan yang terjadi terkait perumusan output Kegiatan pada tahun 2009-2010 telah membuat beberapa struktur data (diantaranya output) menjadi berubah dan berbeda antar tahun.

Pokok dari penelitian ini adalah penerapan at cost, karena itu diperlukan titik kapan penerapan at cost tersebut 
dilakukan. Meskipun semenjak PMK 45/PMK.05/2007 yang mengatur at cost menyatakan berlaku pada saat PMK tersebut diundangkan, pada penelitian ini digunakan asumsi bahwa penerapan at cost dilaksanakan pada tahun 2008 dengan pertimbangan bahwa pada tahun 2007 fasilitas yang mendukung terlaksananya mekanisme at cost belum tersedia dengan baik, dan baru pada tahun 2008 bisa dikatakan cukup baik.

\section{TINJAUAN PUSTAKA}

\subsection{Teori kebijakan}

Menurut definisi KBBI, kebijakan adalah :

Kebijakan/ke.bi·jak·an/ n 1 kepandaian; kemahiran; kebijaksanaan; 2 rangkaian konsep dan asas yg menjadi garis besar dan dasar rencana dl pelaksanaan suatu pekerjaan, kepemimpinan, dan cara bertindak (tt pemerintahan, organisasi, dsb); pernyataan cita-cita, tujuan, prinsip, atau maksud sbg garis pedoman untuk manajemen dl usaha mencapai sasaran; garis haluan:

Menurut Ealau dan Pewitt (1973) kebijakan adalah sebuah ketetapan yang berlaku,dicirikan oleh perilaku yang konsisten dan berulang baik dari yang membuat atau yang melaksanakan kebijakan tersebut. Menurut Titmuss (1974) mendefinisikan kebijakan sebagai prinsip-prinsip yang mengatur tindakan dan diarahkan pada tujuam tertentu dan menurut Edi Suharto (2008:7) menyatakan bahwa kebijakan adalah suatu ketetapan yang memuat prinsip-prinsip untuk mengarahkan cara bertindak yang dibuat secara terencana dan konsisten dalam mencapai tujuan tertentu.

Dalam lingkup publik, dikenal adanya kebijakan publik. Kebijakan publik menurut Anderson (1975) adalah kebijakan kebijakan yang dibangun oleh badan-badan dan pejabat-pejabat pemerintah, di mana implikasi dari kebijakan tersebut adalah: 1) kebijakan publik selalu mempunyai tujuan tertentu atau mempunyai tindakan-tindakan yang berorientasi pada tujuan; 2) kebijakan publik berisi tindakan-tindakan pemerintah; 3) kebijakan publik merupakan apa yang benar-benar dilakukan oleh pemerintah, jadi bukan merupakan apa yang masih dimaksudkan untuk dilakukan; 4) kebijakan publik yang diambil bisa bersifat positif dalam arti merupakan tindakan pemerintah mengenai segala sesuatu masalah tertentu, atau bersifat negatif dalam arti merupakan keputusan pemerintah untuk tidak melakukan sesuatu; 5) kebijakan pemerintah setidak-tidaknya dalam arti yang positif didasarkan pada peraturan perundangan yang bersifat mengikat dan memaksa

\subsection{Teori alokasi anggaran}

Menurut definisi KBBI, alokasi adalah: Alokasi/alo·ka·si/ n Ek 1 penentuan banyaknya barang yg disediakan untuk suatu tempat (pembeli dsb); penjatahan; 2 penentuan banyaknya uang (biaya) yg disediakan untuk suatu keperluan: Pemerintah memberi -- dana kpd tiap desa untuk membangun gedung sekolah dasar; 3 Sos pembagian pengeluaran dan pendapatan (di suatu departemen, instansi, atau cabang perusahaan), baik dl 
perencanaan maupun pelaksanaannya; 4 Man penentuan penggunaan sumber daya secara matematis ( $\mathrm{msl}$ tt tenaga kerja, mesin, dan perlengkapan) demi pencapaian hasil yg optimal;

Menurut Mardiasmo (2002:61): "Anggaran merupakan pernyataan mengenai estimasi kinerja yang hendak dicapai selama periode waktu tertentu yang dinyatakan dalam ukuran financial, sedangkan penganggaran adalah proses atau metoda untuk mempersiapkan suatu anggaran."

Untuk menyusun suatu anggaran, organisasi harus mengembangkan lebih dahulu perencanaan strategis. Melalui perencanaan strategis terserbut, anggaran mendapatkan kerangka acuan strategis. Di sini, anggaran menjadi bermakna sebagai alokasi sumber daya berupa keuangan untuk mendanai berbagai program dan kegiatan.

\subsection{Perjalanan Dinas}

Definisi perjalanan dinas menurut KBBI:

Per.Ja·lan·an n 1 perihal (cara, gerakan, dsb) berjalan: krn kakinya cacat, nya tidak sempurna; 2 kepergian (perihal bepergian) dr suatu tempat dsb ke tempat dsb yg lain: ia mendapat kecelakaan dl $\sim$ ke Jakarta; 3 jarak (jauh) yg dicapai dng berjalan dl waktu yg tertentu: jauhnya kira-kira dua jam ; 4 perbuatan; kelakuan; tingkah laku: ia bertanya kpd saya bagaimana pegawai baru itu sebelum bekerja di sini;

Di.nas $1 \mathrm{n}$ bagian kantor pemerintah yg mengurus pekerjaan tertentu; jawatan: -Lalu Lintas dan Angkutan Jalan Raya; 2 n segala sesuatu yg bersangkutan dng jawatan (pemerintah), bukan swasta: surat
--; pekerjaan --; 3 v cak bertugas, bekerja (dl jawatan pemerintah): di mana kau -sekarang?;

Berdasarkan definisi kedua kata tersebut, dapat ditarik disimpulkan yang dimaksud dengan perjalanan dinas adalah perihal bepergian dari suatu tempat ke tempat yang lain karena bekerja. Dalam pelaksanaannya, karena perpindahan tersebut memerlukan biaya-biaya maka kepada pegawai diberikan fasilitas perjalanan dinas berupa uang harian, uang transportasi, dan penginapan (jika diperlukan). Pada prinsipnya, fasilitas tersebut merupakan biaya karena tidak bersifat menambah penghasilan.

Pengaturan mengenai perjalanan dinas itu diatur oleh Menteri Keuangan selaku Chief Financial Officer dalam Pemerintahan Republik Indonesia. Dalam bentuk pengaturannya, Kewenangan Menteri Keuangan tersebut didelegasikan menjadi dua kewenangan yang diberikan kepada Direktorat Jenderal Anggaran yang mengatur mengenai besaran standar biayanya, dan Direktorat Jenderal Perbendaharaan yang mengatur mengenai mekanisme perjalanan dinasnya. PMK Nomor 45/PMK.02/2007 adalah terbitan Direktorat Jenderal Perbendahaaran yang bersifat mengatur mekanisme. Pada perjalanannya, PMK tersebut melalui beberapa kali revisi dan terakhir dicabut dengan PMK No.113/PMK.05/2012 yang tetap mempertahankan pengaturan mekanisme at cost.

Terdapat dua klasifikasi perjalanan dinas, yakni perjalanan dinas dalam negeri dan perjalanan dinas luar negeri. Perjalanan dinas dalam negeri diatur dalam PMK Nomor 45/PMK.02/2007 jo. 
PMK No.113/PMK.05/2012, Sedangkan untuk Perjalanan Dinas Luar Negeri diatur melalui Peraturan Menteri Keuangan Nomor 97/PMK.05/2010, Terdapat tiga komponen dalam perjalanan dinas yaitu uang harian, tranportasi, dan penginapan. Perlu disampaikan bahwa, pengaturan at cost dalam perjalanan dinas dalam negeri adalah pada komponen transportasi (tiket) dan hotel. Sedangkan pada perjalanan dinas luar negeri, hanya transportasi yang diberikan at cost karena uang penginapan digabungkan dengan uang harian yang diberikan secara lumpsum.

Menurut kedua peraturan tersebut, Perjalanan Dinas Dalam Negeri, didefinisikan sebagai: perjalanan ke luar tempat kedudukan yang dilakukan dalam wilayah Republik Indonesia untuk kepentingan negara. Sedangkan Perjalanan Dinas Luar Negeri, yang didefinisikan sebagai: perjalanan baik perseorangan maupun secara bersama untuk kepentingan dinas/negara, dari Tempat Bertolak di Dalam Negeri ke Tempat Tujuan di Luar Negeri, dari Tempat Kedudukan di Luar Negeri/ Tempat Bertolak di Luar Negeri ke Tempat Tujuan di Dalam Negeri, atau dari Tempat Kedudukan di Luar Negeri/Tempat Bertolak di Luar Negeri ke Tempat Tujuan di Luar Negeri, yang dananya bersumber dari Anggaran Pendapatan dan Belanja Negara (APBN).

Terdapat perbedaan antara pengaturan perjalanan dinas yang bersumber dari dana APBN dengan dana APBD. Seorang analis anggaran mengibaratkan keuangan negara sebagai aliran sungai yang terbelah dua, menjadi Anggaran Pusat dan anggaran Daerah.
Dalam UU Nomor 17 tahun 2003 disebutkan dalam pasal bahwa keuangan daerah diserahkan kepada pemerintahan daerah. Sebagai pembina keuangan daerah dipegang oleh Kementerian Dalam Negeri. Perjalanan dinas yang dilakukan oleh Pemerintah Daerah, dan Pimpinan serta Anggota DPRD diatur dalam Peraturan Menteri Dalam Negeri Republik Indonesia, yang terakhir adalah Permendagri Nomor 37 Tahun 2014 yang (serupa dengan pengaturan pada APBN) mengatur uang transportasi dan penginapan dibayar secara at cost dan uang harian secara lumpsum.

Namun khusus untuk DPR yang merupakan bagian dari Kementerian/Lembaga, biarpun samasama menggunakan dana APBN, perjalanan dinas Pimpinan dan Anggota Dewan Perwakilan Rakyat Republik Indonesia diatur tersendiri dalam Peraturan Pemerintah Nomor 61 Tahun 1990 yang mengatur perjalanan dinas untuk Pimpinan dan anggota DPR secara lumpsum.

$\begin{array}{rrr}\text { Terkait } & \text { dengan } & \text { sistem } \\ \text { penganggaran, } & \text { perjalanan } & \text { dinas }\end{array}$
menempati pos akun belanja 524. Dalam penganggaran di Indonesia dikenal adanya pembagian Jenis Belanja yang terdiri dari: (1) Aset; (2) Kewajiban (3) Ekuitas Dana (4) Pendapatan; (5) Belanja; (6) Transfer untuk daerah; (7) Pembiayaan. Dan (8) Non Anggaran. Pengeluaran atau belanja dibagi menjadi (51) Belanja Pegawai, (52) Belanja Barang (Belanja Perjalanan terdapat pada sub Belanja Barang dengan akun 524), (53) Belanja Modal, (54) Pembayaran Utang (55) Belanja Subsidi (56) Belanja Hibah (57) Belanja Bantuan Sosial, dan (58) Belanja 
lain-lain. Pengaturan sebagaimana tersebut diatur melalui PMK Nomor 91/PMK.05/2007 jo. PMK No. 214/PMK.05/2013 tentang Bagan Akun Standar. Bagan Akun Standar adalah daftar kodefikasi dan klasifikasi terkait transaksi keuangan yang disusun secara sistematis sebagai pedoman dalam perencanaan, penganggaran, pelaksanaan anggaran, dan pelaporan keuangan pemerintah

Belanja Perjalanan dalam Negeri mendapat kode akun 52411, dan Belanja Perjalanan Luar Negeri mendapat kode akun 52421 dengan sub akun 6 digit sebagaimana berikut:

Tabel 1.1 Akun dan Kode Akun Perjalanan Dinas Dalam dan Luar Negeri

\begin{tabular}{|l|l|l|}
\hline $\begin{array}{l}\text { Belanja } \\
\text { perjalanan } \\
\text { dinas } \\
\text { dalam } \\
\text { negeri } \\
52411\end{array}$ & 524111 & $\begin{array}{l}\text { Belanja perjalanan } \\
\text { dinas biasa }\end{array}$ \\
\cline { 2 - 3 } & 524112 & $\begin{array}{l}\text { Belanja perjalanan } \\
\text { dinas tetap }\end{array}$ \\
\cline { 2 - 3 } & 524113 & $\begin{array}{l}\text { Belanja perjalanan } \\
\text { dinas dalam kota }\end{array}$ \\
\cline { 2 - 3 } & 524114 & $\begin{array}{l}\text { Belanja paket } \\
\text { meeting dalam } \\
\text { kota }\end{array}$ \\
\cline { 2 - 3 } $\begin{array}{l}\text { Belanja } \\
\text { perjalanan } \\
\text { dinas luar } \\
\text { negeri } \\
52421\end{array}$ & 524119 & $\begin{array}{l}\text { Belanja paket } \\
\text { meeting luar kota }\end{array}$ \\
\cline { 2 - 3 } & 524212 & $\begin{array}{l}\text { Belanja perjalan } \\
\text { biasa - Luar } \\
\text { Negeri }\end{array}$ \\
\hline $\begin{array}{l}\text { Belanja Perjalanan } \\
\text { dinas tetap - Luar } \\
\text { negeri }\end{array}$ \\
\cline { 2 - 3 }
\end{tabular}

Komponen yang diatur dalam pengaturan PMK 45 jo PMK 113 adalah terdapat dalam akun 524111 yang detilnya terdiri dari Belanja Uang Harian, Belanja Transportasi, dan Belanja Penginapan.
Kegiatan Paket meeting (berdasarkan standar biaya terdiri dari paket yang disediakan hotel untuk keperluan meeting terdiri dari half day/paket setengah hari-5 jam, fullday-paket sehari 8 jam, dan fullboard-paket termasuk menginap) sebagai fasilitasi dari rapat, seminar, dan sejenisnya yang dilaksanakan diluar kota menggunakan akun 524119 Sesuai Perdirjen Perbendaharaan No. PER22/PB/2013, dan Surat Dirjen PB No. S4599/PB/2013.

\subsection{At cost dan Lumpsum}

Salah satu latar belakang dikeluarkannya PMK Nomor 45/PMK.05/2007 adalah pertimbangan bahwa pembiayaan untuk perjalanan dinas harus sesuai dengan kebutuhan nyata dan memenuhi kaidah-kaidah pengelolaan keuangan negara. Kebutuhan nyata/riil yang dimaksud ada didalam mekanisme at cost yang merupakan anti tesis dari mekanisme lumpsum.

Mekanisme lumpsum itu sendiri berarti pembiayaan yang diberikan sekaligus kepada yang menjalankan tugas, sedangkan mekanisme at cost berarti biaya dibayarkan sesuai dengan pengeluaran secara riil, dapat diberikan dimuka. Berlawanan dengan mekanisme at cost yang mana jika realisasi pengeluaran kurang dari yang diberikan maka sisanya harus dikembalikan, maka pada mekanisme lumpsum jika pengeluaran lebih kecil daripada pembiayaan yang diberikan maka kelebihannya menjadi hak yang menjalankan tugas.

Perjalanan dinas dan kesejateraan pegawai merupakan isu sentral dari penolakan atas pemberlakuan sistem at 
cost. Merupakan rahasia umum bahwa sistem lumpsum memberikan peluang kepada pegawai untuk menabung kelebihan uang yang diterimanya melalui penghematan yang dilakukan. Misal, daripada memilih tiket perjalanan yang semestinya menggunakan tiket Garuda sesuai standar perjalanan dinas, yang bersangkutan lebih memilih menggunakan maskapai penerbangan lain yang harga tiketnya di bawah harga tiket Garuda untuk dapat mengambil keuntungan dari selisih harga tiket tersebut. Semenjak pemberlakuan at cost, hal tersebut tidak dapat dilakukan lagi yang mana hal tersebut berimbas pada kesejahteraan pegawai yang melakukan perjalanan dinas karena secara otomatis tidak ada celah lagi untuk melakukan penghematan disebabkan yang dibayarkan sesuai dengan harga tiket.

\section{METODE PENELITIAN}

\subsection{Jenis Penelitian}

Menurut Kuncoro (2009, 10), terdapat 5 jenis penelitian berdasarkan metode yang dilakukan dalam penelitian tersebut yaitu: penelitian historis; deskriptif; korelasional; kausal komparatif; dan eksperimental. Maka penelitian ini termasuk dalam jenis penelitian korelasional yaitu penelitian yang bertujuan menentukan apakah terdapat asosiasi antara 2 variabel atau lebih, serta seberapa jauh korelasi yang ada di antara variabel yang diteliti. Namun terdapat suatu hal yang perlu diperhatikan, bahwa penelitian korelasi tidak menjelaskan sebab-akibat dari setiap variabelnya, melainkan hanya menjelaskan ada atau tidak adanya hubungan antara variabel yang diteliti.

Jenis data yang digunakan dalam studi ini ialah data panel berupa data pooled yaitu kombinasi data yang memiliki elemen runtun waktu dan crosssection (Gujarati, 2004: 28). Data yang digunakan terdiri dari $63 \mathrm{~K} / \mathrm{L}$ dengan waktu penelitian pada data anggaran tahun 2005 hingga 2011. Data panel dipilih karena beberapa keunggulan di antaranya (Baltagi, 2005: 46):

1. Data panel yang merupakan gabungan dua jenis data cross-section dan time series, mampu menyediakan data yang lebih banyak sehingga memberikan informasi yang lebih banyak, lebih beragam, sedikit kolinearitas antarvariabel, menghasilkan degree of freedom lebih besar, dan lebih efisien;

2. Dengan mempelajari unit cross-section yang berulang-ulang, maka penggunaan data panel lebih baik dalam mempelajari adanya perubahan dinamis;

3. Dapat lebih baik mendeteksi dan mengukur pengaruh suatu variabel yang tidak diperoleh jika mengobservasi dengan data murni cross-section atau murni time series.

4. Memungkinkan peneliti untuk mempelajari suatu model perilaku yang lebih kompleks.

5. Secara sederhana, penggunaan data panel dapat memperkaya analisis empiris yang mungkin tidak dapat ditemukan jika hanya menggunakan data runtun waktu saja atau data crosssection saja.

Data yang digunakan dalam kajian ini diambil dari business inteligence (BI) 
DJA, standar biaya masukan (SBM) untuk besaran satuan biaya uang harian, satuan biaya uang tiket, dan satuan biaya penginapan. Data pagu yang digunakan adalah data pagu Perpres.

\subsection{Strategi identifikasi}

Perjalanan dinas dari setiap $\mathrm{K} / \mathrm{L}$ merupakan hasil dari proses produksi dengan memanfaatkan sumber daya yang tersedia dari beberapa variabel yaitu pagu $\mathrm{K} / \mathrm{L}$, belanja barang, dan uang harian. Maka fungsi produksi dari perjalanan dinas adalah:

Perjadin $=f($ PAGU, BBARANG, UHARIAN $)$

Keterangan:

PAGU $=$ pagu anggaran $\mathrm{K} / \mathrm{L}$

(Rupiah)

BBARANG = belanja barang $\mathrm{K} / \mathrm{L}$

(Rupiah)

UHARIAN = besar uang harian sesuai SBU/SBM (Rupiah)

Secara umum dengan menggunakan data panel akan menghasilkan intersep dan slope koefisien yang berbeda pada setiap provinsi dan setiap periode waktu. Dengan demikian, dalam mengestimasi model data panel, akan tergantung dari asumsi yang dibuat tentang intersep, koefisien slope, dan variabel gangguannya. Beberapa kemungkinan yang muncul yaitu (Widarjono, 2009):

1. Intersep dan slope tetap sepanjang waktu dan provinsi. Maka perbedaan intersep dan slope dijelaskan oleh variabel gangguan.

2. Slope tetap dan intersep berbeda antarprovinsi.
3. Slope tetap dan intersep berbeda baik antarwaktu maupun antarprovinsi.

4. Slope dan intersep berbeda antarprovinsi.

5. Slope dan intersep berbeda antarwaktu dan antarprovinsi.

Terdapat beberapa metode yang secara umum digunakan untuk mengestimasi model regresi dengan data panel yaitu:

1. Koefisien tetap antarwaktu dan individu (common effect)

Pendekatan ini menggunakan metode OLS biasa untuk mengestimasi model data panel. Dalam pendekatan ini tidak memperhatikan dimensi individu maupun waktu. Diasumsikan bahwa perilaku data antarprovinsi sama dalam berbagai kurun waktu.

Bentuk model persamaan regresi secara umum sebagai berikut:

$$
Y_{i t}=\beta_{0}+\beta_{1} X_{i t}+\varepsilon_{i t}
$$

Keterangan:

$\mathrm{Y}_{\mathrm{it}}=$ variabel dependen dari individu $\mathrm{i}$ pada kurun waktu $\mathrm{t}$

$\mathrm{X}_{\mathrm{it}}=$ variabel independen dari individu i pada kurun waktu $\mathrm{t}$

$\varepsilon_{\mathrm{it}}=$ error term

2. Slope konstan dan intersep berbeda antarindividu (fixed effect)

Asumsi pada common effect dinilai tidak mencerminkan kondisi sebenarnya. Karakteristik dari beberapa individu (provinsi) jelas akan berbeda. Salah satu cara paling sederhana untuk mengetahui adanya perbedaan adalah dengan mengasumsikan bahwa intersep berbeda antarindividu (provinsi) sedangkan slopenya tetap sama 
antarindividu (provinsi). Bentuk model FE secara umum ialah:

$$
Y_{i t}=\beta_{0 i}+\beta_{1} X_{i t}+\varepsilon_{i t}
$$

Keterangan:

$\mathrm{Y}_{\mathrm{it}}=$ variabel dependen dari individu $\mathrm{i}$

pada kurun waktu $\mathrm{t}$

$X_{i t}=$ variabel independen dari individu

i pada kurun waktu $\mathrm{t}$

$\varepsilon_{\mathrm{it}}=$ error term

Pada model tersebut intersep $\beta$ diberikan subkrip i untuk menunjukkan bahwa intersep dari seluruh individu (provinsi) dimungkinkan berbeda.

Adanya perbedaan intersep dalam model fixed effect, ditangkap dengan penggunaan variabel dummy dalam model estimasi. Tehnik ini dikenal dengan tehnik least squares dummy variables (LSDV). Penggunaan dummy juga bertujuan untuk mewakili ketidaktahuan peneliti tentang model yang sebenarnya.

\section{Random effect}

Penggunaan variabel dummy dalam model fixed effect (FE) membawa konsekuensi berkurangnya derajat kebebasan (degree of freedom) yang pada akhirnya mengurangi efisiensi parameter. Masalah ini dapat diatasi dengan penggunaan variabel gangguan (error terms) yang dikenal dengan metode random effect (RE). Variabel gangguan dari metode estimasi data panel ini, mungkin saling berhubungan antarwaktu dan antarindividu.

Asumsi yang digunakan adalah intersepnya merupakan variabel random atau stokastik. Maka model RE secara umum ialah

$$
Y_{i t}=\beta_{0 i}+\beta_{1} X_{i t}+\varepsilon_{t}
$$

Keterangan:

$\mathrm{Y}_{\text {it }} \quad=$ variabel dependen dari individu $\mathrm{i}$ pada kurun waktu t

$\mathrm{X}_{\mathrm{it}} \quad=$ variabel independen dari individu i pada kurun waktu $\mathrm{t}$

$\varepsilon_{\mathrm{t}} \quad=$ error term

Dalam hal ini $\beta_{0 i}$ tidak lagi tetap tetapi bersifat random sehingga dapat dituliskan kembali dalam persamaan sebagai berikut:

$$
\beta_{0 i}=\bar{\beta}_{0}+\mu_{i} \text { yaitu } i=1, \ldots . n
$$

$\bar{\beta}_{0}$ adalah parameter yang tidak diketahui yang menunjukkan rata-rata intersep populasi dan $\mu$ adalah variabel gangguan yang bersifat random yang menjelaskan adanya perbedaan perilaku provinsi secara individu. Dalam hal ini, variabel gangguan $\mu_{\mathrm{i}}$ memiliki karakteristik sebagai berikut:

$$
\mathrm{E}\left(\mu_{\mathrm{i}}\right)=0 \text { dan } \operatorname{var}\left(\mu_{\mathrm{i}}\right)=\sigma_{\mu}^{2}
$$

Sehingga $\mathrm{E}\left(\beta_{0 \mathrm{i}}\right)=\bar{\beta}_{0}$ dan $\operatorname{var}\left(\beta_{0 \mathrm{i}}\right)=\sigma_{\mu}^{2}$

Maka persamaan RE menjadi:

$$
\begin{aligned}
Y_{i t} & =\left(\bar{\beta}_{0}+\mu_{i}\right)+\beta_{1} X_{i t}+e_{i t} \\
& =\bar{\beta}_{0}+\beta_{1} X_{i t}+\left(e_{i t}+\mu_{i}\right) \\
& =\bar{\beta}_{0}+\beta_{1} X_{i t}+v_{i t}
\end{aligned}
$$

Yaitu $v_{i t}=e_{i t}+\mu_{i}$ yang berarti bahwa variabel gangguan $v_{\text {it }}$ terdiri dari dua komponen berupa variabel gangguan secara menyeluruh $\mathrm{e}_{i t}$ (kombinasi time series dan cross section) serta variabel gangguan secara individu $\mu_{\mathrm{i}}$. Variabel gangguan $\mu_{\mathrm{i}}$ adalah berbeda-beda antarindividu tetapi tetap antarwaktu. Dengan demikian model RE juga disebut sebagai error component model (ECM).

Asumsi yang berkaitan dengan variabel gangguan $v_{\text {it }}$ adalah sebagai berikut:

a. Nilai harapan variabel gangguan nol $E\left(v_{\text {it }}\right)=0$ 
b. Varian variabel gangguan homoskedastisitas $\operatorname{Var}\left(\mathrm{v}_{\mathrm{it}}\right)=\sigma_{\mu}^{2}+\sigma_{e}^{2}$

c. Variabel gangguan dari provinsi yang sama dalam periode yang berbeda saling berkorelasi cov $\left(\mathrm{v}_{\mathrm{it}}, \mathrm{v}_{\mathrm{is}}\right)=\sigma_{\mu}^{2}(\mathrm{t} \neq$ s)

d. Variabel gangguan dari provinsi yang berbeda tidak berkorelasi $\operatorname{cov}\left(\mathrm{v}_{\mathrm{it}}, \mathrm{v}_{\mathrm{js}}\right)=$ $0(i \neq j)$.

Adanya korelasi antara variabel gangguan dalam model RE menyebabkan metode OLS tidak bisa digunakan untuk mendapat estimator yang efisien. Metode yang tepat digunakan untuk mengestimasi model RE adalah generalized least squares (GLS).

Sebelum melakukan estimasi, terlebih dahulu dilakukan uji akar unit (unit root) dari masing-masing variabel. Pada dasarnya, uji akar unit dilakukan pada data panel untuk meningkatkan kekuatan dari hasil estimasi (Baltagi, et al., 2007).

Pemilihan tehnik estimasi model regresi data panel sebagaimana disebutkan di atas, ditentukan dengan beberapa uji statistik untuk menemukan model terbaik yang digunakan untuk mengestimasi model regresi. Maka beberapa uji tersebut di antaranya:

1. Uji signifikansi FE

Keputusan untuk menambahkan variabel dummy untuk mengetahui bahwa intersep berbeda antarprovinsi dengan metode FE dapat ditunjukkan dengan uji $F$ statistik. Uji $F$ ini merupakan uji perbedaan dua regresi yang juga dikenal dengan uji Chow. Uji $\mathrm{F}$ digunakan untuk mengetahui apakah tehnik regresi data panel dengan FE lebih baik dari model regresi data panel tanpa variabel dummy. Hal ini dilakukan dengan melihat residual sum of squares (RSS) dari masing-masing model. Adapun uji $\mathrm{F}$ statistiknya adalah sebagai berikut:

$$
F=\frac{\left(R S S_{1}-R S S_{2}\right) / m}{\left(R S S_{2}\right) /(n-k)}
$$

\section{Keterangan:}

$\mathrm{RSS}_{1}=$ residual sum of squares tehnik tanpa variabel dummy

$\mathrm{RSS}_{2}=$ residual sum of squares tehnik $\mathrm{FE}$ dengan variabel dummy

$m=$ jumlah restriksi atau pembatasan di dalam model tanpa variabel dummy

$\mathrm{n} \quad=$ jumlah observasi

$\mathrm{k}=$ jumlah parameter dalam model FE

dengan hipotesis sebagai berikut:

$\mathrm{H}_{0}=$ common effect

$\mathrm{H}_{1}=$ fixed effect

Nilai statistik $F$ hitung akan mengikuti distribusi statistik $F$ dengan derajat kebebasan (df) sebanyak $m$ untuk numerator dan sebanyak $n-k$ untuk denumetor. Maka jika $\mathrm{F}$ hitung lebih besar dari $\mathrm{F}$ statistik, maka menolak $\mathrm{H}_{0}$ yang artinya model FE dengan tehnik LSDV adalah model data panel yang lebih tepat dibandingkan dengan common effect (CE).

2. Uji signifikansi RE

Selanjutnya perlu dilakukan pengujian lain untuk memilih model data panel RE atau $C E$ yang sesuai untuk mengestimasi data panel. Pengujian ini menggunakan uji Lagrange multiplier (LM) yang dikembangkan oleh Breusch Pagan. Uji ini didasarkan pada nilai residual dari metode OLS. Adapun nilai statistik LM dihitung dengan formula sebagai berikut:

$$
\begin{gathered}
L M=\frac{n T}{2(T-1)}\left[\frac{\sum_{i=1}^{n}\left[\sum_{t=1}^{T} \widehat{e_{l t}}\right]^{2}}{\sum_{i=1}^{n} \sum_{t=1}^{T} \hat{e}_{i t}^{2}}-1\right]^{2} \\
=\frac{n T}{2(T-1)}\left[\frac{\sum_{i=1}^{n}\left(T \overline{\hat{e}}_{l}\right)^{2}}{\sum_{i=1}^{n} \sum_{t=1}^{T} \hat{e}_{i t}^{2}}-1\right]^{2}
\end{gathered}
$$


Keterangan:

$\mathrm{n} \quad$ = jumlah individu

$\mathrm{T}=$ jumlah periode waktu

e = residual metode OLS

dengan hipotesis:

$\mathrm{H}_{0}=$ common effect

$\mathrm{H}_{1}=$ random effect

Uji LM ini didasarkan pada distribusi chisquares dengan degree of freedom sebesar jumlah variabel independen. Jika nilai LM lebih besar daripada nilai statistik chisquares, maka $\mathrm{H}_{0}$ ditolak atau metode $\mathrm{RE}$ merupakan metode yang tepat dalam mengestimasi model regresi data panel daripada metode OLS.

3. Uji signifikansi FE atau RE

Terdapat 2 pertimbangan dalam menentukan pemilihan metode estimasi data panel dengan $\mathrm{FE}$ atau RE, yaitu:

a. Keberadaan korelasi antara error terms $\mathrm{e}_{i t}$ dan variabel independen $\mathrm{X}$

Jika diasumsikan terjadi korelasi antara $\mathrm{e}_{\text {it }}$ dan variabel independen $\mathrm{X}$, maka model RE lebih tepat. Begitu juga sebaliknya, jika tidak ada korelasi antara $\mathrm{e}_{\text {it }}$ dan variabel independen $\mathrm{X}$, maka model FE lebih tepat.

b. Jumlah sampel dalam penelitian

Jika sampel yang digunakan hanya sebagian kecil dari populasi, maka akan diperoleh error terms $e_{i t}$ yang bersifat random sehingga model RE lebih tepat.

Namun demikian, terdapat uji formal yang dikembangkan oleh Hausman mengenai uji statistik untuk memilih menggunakan model FE atau RE. uji ini didasarkan pada ide bahwa LSDV dalam metode FE dan GLS adalah efisien, sedangkan metode OLS tidak efisien. Oleh karena itu, hipotesis nolnya adalah hasil estimasi keduanya tidak berbeda sehingga uji Hausman dapat dilakukan berdasarkan perbedaan estimasi tersebut. Unsur penting untuk uji ini adalah kovarian matrik dari perbedaan vektor $\left[\hat{\beta}-\hat{\beta}_{G L S}\right]$ :

$$
\begin{array}{r}
\operatorname{Var}\left[\hat{\beta}-\hat{\beta}_{G L S}\right]=\operatorname{Var}[\hat{\beta}]+\operatorname{Var}\left[\hat{\beta}_{G L S}\right]- \\
\operatorname{Cov}\left[\hat{\beta}, \hat{\beta}_{G L S}\right]- \\
\operatorname{Cov}\left[\hat{\beta}, \hat{\beta}_{G L S}\right]^{\prime}
\end{array}
$$

Hasil metode Hausman adalah bahwa perbedaan kovarian dari estimator yang efisien dengan estimator yang tidak efisien adalah nol, sehingga:

$$
\begin{aligned}
\operatorname{Cov}\left[\left(\hat{\beta}-\hat{\beta}_{G L S}\right), \hat{\beta}_{G L S}\right] & \\
& =\operatorname{Cov}\left[\hat{\beta}, \hat{\beta}_{G L S}\right] \\
& -\operatorname{Var}\left[\hat{\beta}_{G L S}\right]=0 \\
\operatorname{Cov}\left(\hat{\beta}, \hat{\beta}_{G L S}\right) & =\operatorname{Var}\left(\hat{\beta}_{G L S}\right)
\end{aligned}
$$

Maka jika disubtitusikan, menghasilkan kovarian matriks sebagai berikut:

$$
\begin{gathered}
\operatorname{Var}\left[\hat{\beta}-\hat{\beta}_{G L S}\right]=\operatorname{Var}[\hat{\beta}]-\operatorname{Var}\left[\hat{\beta}_{G L S}\right] \\
=\operatorname{Var}(\hat{q})
\end{gathered}
$$

Selanjutnya mengikuti kriteria Wald, Uji Hausman ini akan mengikuti distribusi ChiSquares sebagai berikut:

$$
m=\hat{q}^{\prime} \operatorname{Var}(\hat{q})^{-1} \hat{q}
$$

yaitu $\widehat{q=}\left[\hat{\beta}-\hat{\beta}_{G L S}\right]$ dan $\operatorname{Var}(\hat{q})=$ $\operatorname{Var}[\hat{\beta}]-\operatorname{Var}\left[\hat{\beta}_{G L S}\right]$,

dengan degree of fredom sebanyak $\mathrm{k}$ jumlah variabel independen. Jika nilai statistik Hausman lebih besar dari nilai kritisnya, maka model yang tepat adalah model FE.

Selanjutnya mengikuti kriteria Wald, Uji Hausman ini akan mengikuti distribusi Chi-Squares, dengan degree of fredom sebanyak $k$ jumlah variabel independen. Jika nilai statistik Hausman lebih besar dari nilai kritisnya, maka model yang tepat adalah model FE. Sedangkan jika sebaliknya, maka model yang tepat adalah model RE. Beberapa hasil pengujian 
pemilihan model data panel tersebut dirangkum oleh Park (2011) yang diuraikan pada tabel sebagai berikut.

\section{Tabel 3.1 Pengujian Pemilihan Model} Data Panel

\begin{tabular}{|l|l|l|}
\hline \multicolumn{1}{|c|}{$\begin{array}{c}\text { Fixed Effect } \\
\text { (uji F) }\end{array}$} & \multicolumn{1}{|c|}{$\begin{array}{c}\text { Random Effect } \\
\text { (uji B-P LM) }\end{array}$} & \multicolumn{1}{c|}{ Model yang dipilih } \\
\hline $\begin{array}{l}\text { Gagal menolak } \mathrm{H}_{0} \\
\text { (bukan fixed effect) }\end{array}$ & $\begin{array}{l}\text { Gagal menolak } \mathrm{H}_{0} \\
\text { (bukan random } \\
\text { effect) }\end{array}$ & Pooled OLS \\
\hline $\begin{array}{l}\mathrm{H}_{0} \text { ditolak } \\
\text { (fixed effect) }\end{array}$ & $\begin{array}{l}\text { Gagal menolak } \mathrm{H}_{0} \\
\text { (bukan random } \\
\text { effect) }\end{array}$ & Model fixed effect \\
\hline $\begin{array}{l}\text { Gagal menolak } \mathrm{H}_{0} \\
\text { (bukan fixed effect) }\end{array}$ & $\begin{array}{l}\text { Menolak } \mathrm{H}_{0} \\
\text { (random effect) }\end{array}$ & Model random effect \\
\hline $\begin{array}{l}\mathrm{H}_{0} \text { ditolak } \\
\text { (fixed effect) }\end{array}$ & $\begin{array}{l}\text { Menolak } \mathrm{H}_{0} \\
\text { (random effect) }\end{array}$ & $\begin{array}{l}\text { Memilih fixed effect jika } \mathrm{H}_{0} \text { dari } \\
\text { uji Hausman ditolak, dan } \\
\text { sebaliknya maka memilih model } \\
\text { random effect }\end{array}$ \\
\hline Sumber: Park, 2011 & \multicolumn{2}{|l}{}
\end{tabular}

\subsection{Jenis data}

Jenis data yang digunakan adalah data sekunder berupa observasi terhadap data anggaran kementerian negara/lembaga pada server DJA yang diakses melalui business intelligence. Data anggaran yang ada di server DJA dimulai dari TA 2005, meliputi pagu dan realisasi, sampai dengan data terakhir (saat penulisan ini) adalah data anggaran TA 2015 yang belum mencakup data realisasi. Data tersebut berupa data kuantitatif yang bersifat data rasio (berbentuk angka dalam arti yang sesungguhnya). Data yang diambil adalah data anggaran perjalanan dinas dan total anggaran pada pagu Keppres APBN.

\subsection{Populasi/sampel}

Populasi/sampel yang digunakan adalah Kementerian Negara/lembaga yang menggunakan dana APBN pada kurun waktu 2005 s.d 2011 (jangka waktu 7 tahun). Namun terkait dengan beberapa hal yang menjadikan beberapa data $\mathrm{K} / \mathrm{L}$ outlier sehingga perlu dikeluarkan dari sampel, yaitu K/L yang tidak secara konsisten muncul dalam rentang waktu 7 tahun tersebut.

Selain itu, terdapat pula K/L yang sama sekali atau dalam rentang waktu tertentu tidak memiliki biaya perjalanan dinas, terhadap K/L seperti ini juga tidak dijadikan sampel penelitian.

\section{PEMBAHASAN}

\subsection{Hasil Pengolahan Data}

Pengolahan data menggunakan Uji Beda dan Regresi Statistika

\subsubsection{Uji Beda}

Untuk mengetahui adakah perbedaan antara sebelum dan sesudah penerapan at cost. Namun sebelumnya perlu dilakukan uji normalitas untuk menilai bahwa pengujian yang dilakukan dapat terlaksana dengan baik, maka terlebih dahulu perlu dilakukan pengujian berdasarkan uji normalitas. Jika diperoleh normal maka pengukuran untuk mengetahui adakah perbedaan antara sebelum dan sesudah penerapan at cost menggunakan uji T-test. Jika hasil yang diperoleh tidak normal, maka menggunakan metode Wilcoxon.

Hasil uji normalitas ditunjukkan pada tabel 4.1. Hasil uji tersebut menunjukkan hasil bahwa terdapat anormalitas (tidak normal). Karena hasil uji yang tidak normal, maka pengujian harus dilakukan secara non parametrik menggunakan metode Wilcoxon.

Pengukuran menggunakan metode Wilcoxon memperoleh hasil sebagai pada tabel 4.2. Dari tabel 4.2 dapat kita lihat 
bahwa Asymp. Sig (2 tailed) lebih kecil dari $0.5 \%(0.00)$, yang menunjukkan bahwa terdapat perbedaan antara sebelum dan sesudah penerapan at cost. Artinya, penerapan at cost mempunyai pengaruh terhadap perjalanan dinas.

Tabel 4.1 Tabel Hasil Uji Normalitas

\begin{tabular}{|l|c|c|c|c|c|c|}
\hline \multirow{2}{*}{} & \multicolumn{2}{|c|}{ Kosts of Normality } \\
\cline { 2 - 7 } & Statistic & df & Siq. & Statistic & df & Siq. \\
\hline ratasebelum & .091 & 63 & .200 & .950 & 63 & .012 \\
ratasesudah & .131 & 63 & .009 & .944 & 63 & .006 \\
\hline
\end{tabular}

a. Lilliefors Significance Correction

*. This is a lower bound of the true significance.

Tabel 4.2 Tabel Hasil Uji Wilcoxon

\begin{tabular}{|c|c|c|c|c|}
\hline Wilcoxon & Ranks & & & \\
\hline & & $N$ & Mean Rank & Sum of Ranks \\
\hline \multirow{4}{*}{$\begin{array}{l}\text { ratasesudah - } \\
\text { ratasebelum }\end{array}$} & Negative Ranks & $20^{2}$ & 23.15 & 463.00 \\
\hline & Positive Ranks & $43^{\mathrm{b}}$ & 36.12 & 1553.00 \\
\hline & Ties & $0^{c}$ & & \\
\hline & Total & 63 & & \\
\hline \multicolumn{5}{|c|}{ a. ratasesudah \& ratasebelum } \\
\hline \multicolumn{5}{|c|}{ b. ratasesudah $>$ ratasebelum } \\
\hline \multicolumn{5}{|c|}{ c. ratasesudah $=$ ratasebelum } \\
\hline
\end{tabular}

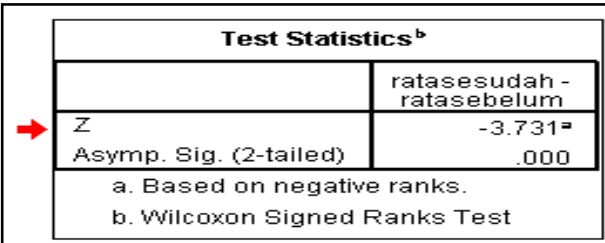

\subsubsection{Regresi Statistika}

Berdasarkan hasil regresi yang didapatkan, ternyata variabel biaya tiket dan biaya hotel tidak secara signifikan mempengaruh biaya perjalanan dinas (hanya variabel tersebut yang lebih besar dari $0,5 \%$, poin signifikansi). Artinya, seluruh variabel lain yaitu pagu perjalanan dinas, belanja barang, dan uang harian, memiliki pengaruh signifikan yang mempengaruhi perjalanan dinas. Nilai R-sq (R Square) within yang diperoleh adalah sebesar 0.4647. nilai ini bermakna bahwa variabel yang dilibatkan disini mempengaruhi sebanyak $46 \%$ dari keseluruhan perjalanan dinas. Hal ini berarti terdapat faktor lain yang mempengaruhi sisa 54\% dari keseluruhan biaya perjalanan dinas.

Lebih lanjut, dengan menggunakan metode OLS dapat secara lebih mendetail diketahui hubungan antara variabel dengan mekanisme at cost. Hasil estimasi perjalanan dinas $\mathrm{K} / \mathrm{L}$ dengan metode OLS ditunjukkan pada tabel 4.3. 
Tabel 4.3 Tabel Hasil estimasi

\begin{tabular}{|c|c|c|}
\hline Variabel & $\begin{array}{c}\text { Koefisien } \\
\text { (nilai t) }\end{array}$ & $\begin{array}{c}\text { Standar } \\
\text { Error }\end{array}$ \\
\hline DPAGU & $\begin{array}{l}0,0097 \\
(4,07)^{*}\end{array}$ & $\begin{array}{r}0,002373 \\
6 \\
\end{array}$ \\
\hline $\begin{array}{l}\text { DBBARAN } \\
\text { G }\end{array}$ & $\begin{array}{r}0,1269 \\
(15,89)^{*}\end{array}$ & $\begin{array}{r}0,007989 \\
7 \\
\end{array}$ \\
\hline LUHARIAN & $\begin{array}{r}2,11 \mathrm{e}+10 \\
(2,54)^{* *}\end{array}$ & $8,30 e+09$ \\
\hline $\mathrm{D}$ & $\begin{array}{r}3,89 e+13 \\
(2,10)^{* *}\end{array}$ & $1,86 e+13$ \\
\hline D*UHAR & $\begin{array}{r}-1,20 e+08 \\
(-2,10)^{* *} \\
\end{array}$ & $5,69 e+07$ \\
\hline _CONS & $\begin{array}{r}-2,24 \mathrm{e}+11 \\
(-2,30)^{* *} \\
\end{array}$ & $9,75 e+10$ \\
\hline \multicolumn{2}{|c|}{$\begin{array}{l}\mathrm{R}^{2} \\
\mathrm{~F} \\
\text { Prob (F-statistik) }\end{array}$} & $\begin{array}{r}0,5609 \\
95,05 \\
0,0000\end{array}$ \\
\hline \multicolumn{3}{|c|}{ Level signifikansi: $* 1 \% * * 5 \%$} \\
\hline
\end{tabular}

Berdasarkan hasil estimasi tersebut di atas, dapat dijelaskan korelasi antara perjalanan dinas dengan variabel-variabel independen yang mempengaruhinya yaitu:

a. Adanya perubahan 1 persen pada pagu anggaran $\mathrm{K} / \mathrm{L}$, akan meningkatkan pagu perjalanan dinas sebesar 0,0097 persen

b. Perubahan 1 persen belanja barang, akan meningkatkan pagu perjalanan dinas sebesar 0,1269 persen

c. Perubahan 1 rupiah uang harian, akan meningkatkan pagu belanja sebesar Rp 21.100.000.000

d. Saat penerapan kebijakan at cost, perjalanan dinas akan meningkat $\mathrm{Rp}$ 38.900.000.000.000 lebih besar dibandingkan saat kebijakan lump-sum

e. Pada saat kebijakan at cost, jika uang harian meningkat $\mathrm{Rp} 1$, maka perjalanan dinas akan menurun sebesar Rp 120.000.000 lebih besar dibandingkan saat kebijakan lump sum diterapkan.

\section{KESIMPULAN}

\subsection{Kesimpulan}

Melalui pengukuran-pengukuran sebagaimana dilakukan pada pembahasan, diperoleh hasil sebagai berikut:

1. Terdapat perbedaan alokasi pagu perjalanan dinas antara sebelum dan sesudah penerapan at cost.

2. Variabel-variabel yang berpengaruh terhadap perjalanan dinas adalah: uang harian, pagu perjalanan dinas, dan pagu belanja barang, dimana variabel-variabel ini mempengaruhi perjalanan dinas sebanyak $56 \%$. Selain itu, terdapat variabel lainnya yang memberikan kontribusi pengaruh sebesar $44 \%$ terhadap perjalanan dinas.

\subsection{Saran}

1. Berdasarkan hasil sebagaimana diperoleh sebelumnya, maka dalam penelitian ini kami merekomendasikan untuk tetap melanjutkan kebijakan yang telah diambil, yaitu tetap melanjutkan penerapan mekanisme at cost pada perjalanan dinas.

2. Untuk pengembangan yang lebih baik, maka perlu dilakukan penelitian lebih lanjut mengenai pengaruh at cost dengan menggunakan data realisasi perjalanan dinas, dan jika memungkinkan untuk melihat sampai sejauhmana tingkat efisiensi yang dihasilkan dari perubahan mekanisme tersebut, karena selama ini terdapat anggapan bahwa penerapan at cost berdampak pada meningkatnya efisiensi perjalanan dinas. 


\section{DAFTAR PUSTAKA}

Anderson, James A. (1975). Public Policy Making: Basic Concept in Political Sciences. New York: Praeger University Series.

Baltagi, Badi H, Georges Bresson, dan Alain Pirotte. 2007. "Panel Unit Root Tests and Spatial Dependence." Journal of Applied Econometrics, 22(2), 339360.

Baltagi, BH., et al., 2007, Testing for Serial Correlation, Spatial Autocorrelation, and Random Effect using Panel Data, Journal of Econometrics, 140, 5-51.

Mardiasmo, Akuntansi Sektor Publik, Penerbit Andi Yogyakarta, 2002, 6174

Park, Hun Myoung. 2011. Practical Guides to Panel Data Modeling: a step by step analysing using stata. Tersedia di:

http://www.iuj.ac.jp/faculty/kucc62 5/method/panel/panel iuj.pdf [2014, 8 Agustus].

Prof. Dr. Nana Syaodih Sukmadinata.2009. Metode Penelitian Pendidikan. Bandung: Pt Remaja Rosdakarya.
Prof.Dr. Sugiyono.2008. Metode Penelitian Pendidikan.Bandung:Penerbit Alfabeta.

Rusdin Pohan, Metodologi Penelitian Pendidikan, Lanarka Publisher, Yogyakarta 2007.

Sarwo,jonathan.2006.Metode Penelitian Kuantitatif dan Kualitatif .Jogja:Graha Ilmu

Suharsimi Arikunto, Prosedur Penelitian: Suatu Pendekatan Praktek, PT Rineka Cipta, Jakarta, 2002.

Suharto, Edi. 2008. Kebijakan Sosial Sebagai Kebijakan Publik.Bandung: Alfabeta

Tejoyuwono Notohadiprawiro dalam makalahnya: Metodologi Penelitian dan Beberapa Implikasinya dalam Penelitian Geografi, Fakultas Geografi UGM, Yogyakarta 1991.

Titmuss, Richard, 1974, Sociol Policy: An Introduction, Alten and Unwin, London

Umi Proboyekti dalam makalahnya: Apa itu Research, Riset atau Penelitian?, Fakultas Teknik UKDW, Yogyakarta.

Widarjono, Agus. 2009. Ekonometrika: pengantar dan aplikasinya. Penerbit Ekonisia. Yogyakarta. 